\title{
Identification in a time of invisibility for American Indians and Alaska Natives in the United States
}

\author{
Michele Connolly ${ }^{\mathrm{a}, *}$, Mehgan Gallagher ${ }^{\mathrm{b}}$, Felicia Hodge ${ }^{\mathrm{c}}$, Mary Cwik $^{\mathrm{d}}$ and, Victoria O’Keefe ${ }^{\mathrm{d}}$, \\ Bette Jacobs ${ }^{\mathrm{e}}$ Amy Adler ${ }^{\mathrm{f}}$ \\ ${ }^{a}$ International Group for Indigenous Health Measurement, Columbia, MD, USA \\ ${ }^{\mathrm{b}}$ Federal Litigation Attorney, Goldberg and Associates, New York City, NY, USA \\ ${ }^{\mathrm{c} S}$ School of Public Health, School of Nursing, University of California, Los Angeles, CA, USA \\ ${ }^{\mathrm{d}}$ Center for American Indian Health, Johns Hopkins Bloomberg School of Public Health, Baltimore, MD, USA \\ e O'Neill Institute for Global Health Law, Georgetown University, Washington, DC, USA \\ ${ }^{\mathrm{f}}$ Independent Consultant on American Indian Issues, Laurel, MD, USA
}

\begin{abstract}
This paper contains an examination of how we identify and describe American Indians and Alaska Natives (AIAN) people, present what we know and discuss how we can develop measures to better improve policies and programs that affect the AIAN people and improve their lives. Specifically, this paper consists what we know about health and socio-demographic characteristics profiles and discussions of current and emerging issues. This paper was written almost entirely by Indigenous people and is an attempt to present research by us, rather than for us or to us.
\end{abstract}

Keywords: Indigenous, identification, American Indian Alaska Native, invisibility, statistics

\section{Overview}

In 2016, the Standing Rock Sioux Tribe of North Dakota was the center of protests concerning the Keystone XL pipeline, which would transport oil from North Dakota to the Gulf of Mexico. The pipeline, originally designed to go underground through Bismarck, the capital of North Dakota, was rerouted to treaty land of the Standing Rock Sioux Tribe. The protestors, who referred to themselves as water protectors, set up camps for many months and garnered world-wide attention. Although the pipeline was built, the water protectors at Standing Rock represented the largest gathering of American Indians and Alaska Na-

\footnotetext{
*Corresponding author: Michele Connolly, International Group on Indigenous Health Measurement, Indigenous Editor, Statistical Journal of the IAOS. Tel.: +1 443812 4289; E-mail: michelebabb@ verizon.net.
}

tives in recent history. After years of invisibility, AIAN people of the US were in the news [1]. ${ }^{1}$

American Indians and Alaska Natives have lived in what is now the United States for tens of thousands of years. AIAN Tribes and communities are resilient and for the most part, have retained their cultures in the face of hundreds of years of wars, displacement and assimilation efforts [1].

There are currently 573 Tribes that are federallyrecognized, that is, recognized by the US government [2] and about 60 Tribes recognized only by states. It is important to note that the designation of Tribes refers to Tribes, bands, Rancherias, pueblos, colonies and villages (in Alaska). Altogether, according to the

\footnotetext{
${ }^{1}$ Portions of this paper were based on Connolly, Michele, "Improving Lives of Indigenous People through Better Statistics: Meeting Policy and program needs", OECD Conference, September 19, 2018 [1].
} 
2010 census, about 5.2 million (1.6 percent) reported their race as AIAN and 2.9 million (0.9 percent) reported AIAN as their only race. Alaska Natives consist of members of Alaska Tribes, Aleuts from the Aleutian Islands and Eskimos, which include the Yupik and Inuit peoples [3]. In the census and other US surveys, a question is asked about race. For those, who report American Indian or Alaska Native, space is provided to record their Tribes [3]. This paper does not cover the 1.1 million (0.4 percent) Indigenous Native Hawaiians and other Pacific Islanders (i.e. Guam, American Samoa), because their legal and political status is so different [4].

Although the AIAN people are the original Americans, their small numbers and the geographic isolation of Reservations and Tribal lands contribute to an invisibility that serves as a major obstacle for almost every issue. Michael Bird, the first AIAN president of the American Public Health Association, recently said this [5]:

"... the knowledge of Indian history among most non-native people in this country is next to nil. For those building policies, it's really important to listen. I would say the major challenge is that, to the American public, Indian people are invisible. They don't see us, they don't think about us, and they don't know the history."

His words are backed up by a recent survey from the Reclaiming Native Truth project, funded by the Kel$\operatorname{logg}$ Foundation, which found that 40 percent of Americans thought that AIAN people no longer exist [6] Clearly, education is required.

The AIAN people are not only invisible in society, but also in data and in policy; which, in turn, must be informed by accurate, reliable and timely data. As a result, data on the AIAN people tend to be limited or even non-existent. Data used for policy often do not include or cannot separate out AIAN people. What we do know, even with imperfect measures, is that AIAN people are much worse off in many ways than the rest of the US population and other racial and ethnic groups. Since many programs require data to even apply, without data, AIAN people and Tribes may be shut out entirely for grants or participation.

Perhaps the greatest barrier to lack of AIAN data is identification, that is, how we describe and identify who is an AIAN. In fact, terminology is confusing. Before settlement by Europeans, people identified themselves by their Tribes. There was no collective term, until the term American Indians was coined under the erroneous assumption that Christopher Columbus had reached India. More recently, the term Native Americans has been used, in addition to American Indians and Alaska Natives. The terms are often used interchangeably. Most AIAN people identify by their Tribes just as they always have.

Often, the AIAN population is viewed as just another racial or ethnic group within the United States, not as Indigenous people, with their own unique history and legal status. While ancestry is often the determining factor for other non-AIAN groups, because the AIAN people are Indigenous, there are a host of historical, legal and political factors, besides ancestry to consider. Ignoring these factors makes identification harder to define for the AIAN population than for other racial and ethnic groups.

\section{History}

To understand how the lives of AIAN people are so different from other Americans and why identification is so complex, we need to start at the beginning and briefly examine American history.

For at least 40,000 years, Indigenous people have been in what is now the US. Christopher Columbus is often credited as the first European to reach North American shores in the Caribbean in 1492. Estimates of the Indigenous population in the US are difficult to reconstruct and vary widely from four to twelve million [7]. As much as half of the population died from war and disease after Europeans came. We do not have a more precise population estimate, but future mitochondrial DNA studies may shed some light. Many European nations colonized what is now the US: Britain, Spain, the Netherlands, Sweden, France and Russia. Each country had different ways of interacting with the AIAN people, but an overall similarity was the regard for American Indian Tribes as sovereign nations, which could be negotiated with through treaties [8]. Many Tribes, including those in California and the southwest, were under the rule of various European governments and Mexico before becoming part of the US. Thus, the history of many Tribes, while unique before European settlement, was also complicated by various European nations that occupied Tribal lands [8].

When the American Revolution established the United States, American policies replaced British policies. For example, many Tribes in the original 13 colonies had treaties with the British Crown, which were largely disregarded by the new American gov- 
ernment; which, in turn, negotiated treaties with Tribes for nearly a century. Treaties and war were the main vehicles for the loss of Indian land. The last treaty was negotiated in 1871 [8]. According to the BIA, there are 326 Indian lands, which are primarily federal Reservations, areas set aside for one or more Tribes "... under treaty, executive order from the President, federal statute or administrative actions..." Other Indian lands include Trust Lands, Historic areas of Oklahoma, pueblos, missions, Rancherias, and villages in Alaska. [8] Collectively, Indian lands are often referred to as Reservations or Indian Country. In addition, some state recognized Tribes live on state Reservations.

American Indian policy, building on the notion of Tribal sovereignty, was first addressed under the Articles of Confederation, which were replaced by the US Constitution enacted in 1789. Article 1 , section 8 calls for Congress to have power to "... regulate commerce with foreign Nations and among the several States, and with the Indian Tribes" [9]. There are many examples of such policies and laws, including the Plenary Power Doctrine through the commerce clause, allows Congress to presume for itself that it has absolute power over AIANs and their resources without consent from Tribes [10], while the President's treaty power extends to Indian affairs [11]. As more settlers moved west into Indian lands, wars occurred, because Indians did not want to give up their lands. Although exact figures are hard to obtain, many Indians were killed from war and disease and many Indian towns and settlements were destroyed. From 1828 to 1887 AIANs faced removal and relocation. The Indian Removal Act of 1830 forced American Indians living largely in southern states to lose their land and move to the Indian Territory of Oklahoma [10]. During the Trail of Tears in 1838, Cherokees were forcibly marched from Georgia to Oklahoma. Numerous treaties occurred in the period up to 1878 resulting in the loss of massive amounts of Indian lands. The creation of Reservations, which began around 1850, resulted in isolating Indians from the rest of the population [8]. Plains Indians faced major loss of their primary food source, with the extermination of the buffalo by 1875 . From 1887 to 1928 , a period of allotment and assimilation ensued where more than two-thirds of existing Reservation lands shrank and the federal government took over jurisdiction of felony crimes [8].

The Indian Wars began in colonial times and continued, according to the US Department of Veterans' Affairs until 1898 [12]. Countless skirmishes and battles occurred until Posey's War in Utah in 1923. The last American veteran from the Indian Wars died in 1973 [13].

After treaties and wars, legislation and policy promoting assimilation began. In 1890, as part of the development of the boarding school system, the Civilization Fund Act funded coordinated separation of AIAN children from their Tribes [14]. The Indian Citizenship Act of 1924 gave American Indians citizenship and the right to vote although some did not get the vote until the early 1970 s after the passage of the Civil Rights Act and Voting Rights Act of 1964/5. In more modern times, the US government attempted to terminate the sovereign status of Tribes. About 100 Tribes were officially terminated from 1953 to 1958 . Many of the terminated Tribes regained federal recognition, while others did not. In the 1960s, the Indian Civil Rights Act and the Indian Self-determination Act began a new era of AIAN policy, bringing the official end of AIAN boarding schools. However, children were still removed from their families and 25-35 percent of all Native children were raised in non-Native homes and institutions during some period of their lives [14]. Alaska became a state in 1959 and the Alaska Native Settlement Act in 1971, resulted in land and subsistence rights for Alaska Natives.

Tribal sovereignty was seen in the early years of the US as a temporary condition before complete assimilation [8]. The tension between the resiliency of AIAN Tribes and communities and growth of the nonnative US population has resulted in a general confusion of what Tribal sovereignty means and, hence what it means to be an AIAN. There are three important United States Supreme Court cases that define modern day AIAN law, referred to as "The Marshall Trilogy" [15]. The Supreme Court held in 1831 in Cherokee Nation v. State of Georgia that a Tribal government is not a "foreign state", within the meaning of the Constitution, and cannot sue in the courts of the United States [16]. Justice John Marshall elaborated on the relationship of Tribes to the United States stating it "resembles that of a ward to his guardian", but state laws "can have no force" [16]. Native Tribes have inherent sovereignty over criminal matters based on the principles these Supreme Court cases and the Constitution, which frees them from state interference, but also subjects them to federal law [17]. Over and over the Supreme Court has affirmed Congress's legislative power over crime in Indian country. In United States v. Rogers, the Court held that "Congress may by law punish any offence [in Native territory], no matter whether the offender be a white man or an Indian." 45 
U.S. (4 How.) 567, 572 (1846) [18]. In United States v. Kagama, the Court upheld Congress's authority to pass the Major Crimes Act based on the federal government's duty to protect the Indian Tribes. 118 U.S. 375, 384 (1886) [19]. In United States v. Antelope, the Court stated, "Congress has undoubted constitutional power to prescribe a criminal code applicable in Indian Country." 430 U.S. 641, 648 (1977) [20].

\section{Identification for American Indians and Alaska Natives}

The identification of who is or is not an American Indian or Alaska Native goes beyond racial groupings and ancestry. The biggest difference between AIAN and other racial and ethnic minorities is Tribal sovereignty, that is, Tribes have a sovereign legal nation-to-nation relationship with the United States. Tribal sovereignty, in a practical sense, means that Tribal members elect their own officials with many have their own constitutions and courts [21]. Tribes get federal recognition through Congress, administrative procedures through the Bureau of Indian Affairs (BIA) or the courts [21]. The number of Tribes (573) is trending upward, with six Tribes added in July 2018 [2].

Tribal membership is based on enrollment criteria set by individual Tribes, often by degree of blood or blood quantum [21]. Typically, one-fourth or more blood quantum is used as the criteria for enrollment. Besides enrolled members, many Tribes have descendent members who are children or grandchildren of enrolled members. Members of federally-recognized Tribes are eligible for certain programs, including the Indian Health Service (IHS). Depending on the program, some state-recognized Indians may be eligible for programs. The legal definition of an AIAN person is at odds with self-reported measures based on ancestry used in the census, other federal surveys and vital records (e.g. birth certificates).

\section{Data sources on American Indians and Aaska Natives}

\subsection{US population data}

The United States leads the world in health surveys and measurement. The world's longest continuous health survey, the National Health Interview Survey, conducted by the National Center for Health
Statistics (NCHS) within the Centers for Disease Control (CDC), has served as a model for other countries. Similar surveys on health measurement and nutrition (the National Health and Nutrition Examination Survey) have a similar impact. The US census, mandated by the US Constitution, has collected data on the resident population since 1790 . The vital statistics system obtains accurate and timely information even though data coordination is complex, with information from counties being sent to states and the District of Columbia and compiled into national figures at NCHS. Great strides have been made to obtain information on racial and ethnic sub-groups within the population, including African-Americans and Hispanics, but not for the AIAN population.

\subsection{US census data}

In modern times, the decennial census is the best source of information on the AIAN population and the only source for small Tribes and communities. The census provides essential information for AIAN Tribes, as results from the census are used to distribute funds from certain programs to Tribes. The census is conducted within the boundaries of the US. Typically, everyone residing in the US is counted on April 1 of the decennial census year. Currently, most census data are collected by mail-in paper forms, but census enumerators conduct personal interviews as well. Interview guides are available in many languages, including AIAN languages. Attempts are made to have AIAN enumerators on or near Reservations. The census is mandatory and there are advertising efforts nationwide for people to participate. Since AIAN people were excluded from the census for many years, as described below, a poster from the 2010 census showing a young man in color and ancestors in black and white that read “... Today, it's my opportunity [to be counted] that my ancestors may not have had..." [22].

The census was not a source of data on the AIAN people for many years. The first mention of American Indians as individuals in regards to the census appears in article 1; section 2 [23], which addresses the mandate for a decennial census to determine the number of representatives in Congress [23]:

“... Representatives... according to their respective Numbers, which shall be determined by adding the whole Number of free Persons, including those bound to service for a Term of Years, and excluding Indians not taxed, three-fifths of all other Persons." 
Although there were some special Tribal censuses, such as the Cherokee census of 1835, American Indians were not counted for purposes of representation in Congress, because they were not citizens. During this time, racial categories were limited to White, Black and Mulatto [7]. It is important to note that some Tribes conducted their own censuses prior to American settlement, often through oral histories and paintings on buffalo hides [22].

Until around 1930, annual and census counts were made by Indian Agents in charge of individual Reservations for reports to Congress and for planning purposes in the War Department. These counts contained criteria about assimilation, such as degree of Indian blood, mode of dress, place of residence, language and lifestyle. Such figures were at best estimates [7]. We know little about these reports, as there were no uniform instructions or standard criteria and no provisions for copies were made.

The General Allotment or Dawes Act, enacted in 1887, allowed enrolled Tribal members to be allotted lands for agriculture and other land use regardless of the actual environment or Tribal culture. In 1890, a special supplement on American Indians was conducted to determine "... the degree to which an Indian had adopted a European way of life..." [7] The national count in 1890 was 237,196 (0.4 percent). The special supplement forms were destroyed in a warehouse fire and never analyzed.

Race was reported by census enumerators based on the perception of the enumerators until self-report began in 1960, with categories of American Indian, Aleut and Eskimo added to the list of races. The US Census Bureau and other US surveys define race as the continent of origin for people or their ancestors. American Indians and Alaska Natives are defined as "... a person having origins in any of the original peoples of North and South America (including Central America) and who maintains Tribal affiliation or community attachment..." [3]. A separate racial category of AIAN was added in 1970, along with space for an individual to write in his or her tribe [7]. Multiple races were allowed in 2000 [3].

As can be seen in Table 1, the numbers of AIAN people are relatively small [24-27]. Although the estimated population of AIAN people prior to the arrival of Europeans may have been as high as 8 million, the estimate of 237,196 (less than a quarter of a million), illustrates the extreme population loss due to disease, war and starvation exacerbated by loss of land [7]. There has been growth in recent decades in numbers and in the percentage of the population, but the population is far from where it was. Still, even using numbers of those who reported AIAN as their only race since 2000, growth has been demographically impossible, that is, it cannot be attributed to births, deaths or migration. One reason is that stigmas have been lifted. Another reason is that Central and South American Indians were included. In 2010, Tribes from Latin America were the fourth largest Tribal designation reported [3].

Many Americans believe that they possess American Indian ancestry, often based on little or no proof. In 2000, 7.9 million (2.8 percent) reported AIAN ancestry, but not necessarily their race. At that time, 4.1 million (1.5 percent) reported AIAN and another race and 2.4 million ( 0.9 percent) reported AIAN as their only race [22]. One of the surprising findings from the Reclaiming Native Truth Project is that in 2018, 36 percent of Americans believed that they have an AIAN ancestor or relative: a figure at odds with the 40 percent who believed AIAN people no longer exist [6].

A recent development in how Americans view their racial background is the popularity of consumer ancestry DNA kits designed to identify family trees and genetic ancestry. These kits can be purchased online and tend to use saliva samples. The kits are easy to use and provide a pie chart with maps of broad geographical swaths where an individual's genetic ancestors could have lived in the last 500 years or so. For example, Native Americans refer to those whose ancestors may have come from the Indigenous people of Canada, the US or Mexico. Genetic ancestry is determined through proprietary algorithms for broad ethnic groups obtained through a reference panel. Genotypes of individuals are matched by percentages with these groups. Siblings have been known to have different ancestry genetic distributions. The current popularity of claiming Native American genetic ancestry is illustrated by the fourth of seven frequently asked questions about the tests in the online advertisement for AncestryDNA ${ }^{\mathrm{TM}}$, " "Can AncestryDNA ${ }^{\mathrm{TM}}$ tell me about my Native American ethnicity?" Cautions are given that results cannot be linked to specific Tribes and cannot take the place of genealogical records kept by the Tribes for enrollment purposes. In general, these companies adjust their genetic ancestry profiles as more people use the kits [28]. A 2018 technical paper from AncestryDNA ${ }^{\mathrm{TM}}$ mentions a sample size of 146 in their reference panel for ethnicity estimates for Indigenous people from North, Central and South America and 63 from the Andes [29]. Tribes have not embraced this new form of determining ethnicity and some refuse to participate. 
Table 1

US Census Counts of American Indians/Alaska Natives

\begin{tabular}{lccc}
\hline Year & Number (AIAN only race) & Number (AIAN and other races) & Total AIAN only race and with other races \\
\hline 1890 & $237,196(0.4 \%)$ & - & $0.4 \%$ \\
1920 & $244,400(0.2 \%)$ & - & $0.2 \%$ \\
1930 & $334,000(0.3 \%)$ & - & $0.3 \%$ \\
1940 & $343,400(0.2 \%)$ & - & $0.2 \%$ \\
1950 & $508,700(0.3 \%)$ & - & $0.3 \%$ \\
1960 (with Alaska) & $551,700(0.3 \%)$ & - & $0.3 \%$ \\
1970 & $827,300(0.4 \%)$ & - & $0.4 \%$ \\
1980 & $1,420,400(0.6 \%)$ & - & $0.6 \%$ \\
1990 & $1,929,200(0.8 \%)$ & $1,643,345(0.6 \%)$ & $0.8 \%$ \\
$2000 *$ & $2,447,989(0.9 \%)$ & $2,288,331(0.7 \%)$ & $4,119,301(1.5 \%)$ \\
$2010 *$ & $2,932,248(0.9 \%)$ & $5,220,579(1.7 \%)$ & \\
\hline
\end{tabular}

*Reporting of multiple races began. Sources: US Census Bureau; Historical Statistics of the United States, Colonial Times to 1970, Bicentennial Edition, Volumes 1 and 2; Washington, Dc; 1975; US Census Bureau; American Indians, Eskimos and Aleuts on Identified Reservations and in the Historic Areas of Oklahoma; PC80-2-1D; Washington DC, Issued January 1986; Griece, Elizabeth and Cassidy, Rachel; US Census Bureau; Overview of Race and Hispanic Origin 2000; C2KBR/01-1; Issued March 2001; Humes, Karen; Jones, Nicholas, and Ramirez, Roberto; US Census Bureau; Overview of Race and Hispanic Origin 2010; C2010BR-02; Issued March 2011.

\subsection{Self-reported identification}

Which AIAN identification works best? The total AIAN population is used as the denominator for critical health and socio-demographic characteristics and trends. Rates based on these denominators vary by the identification method used, which, in turn, is based on willingness to identify as an AIAN amid changing perceptions of ancestry. For example, according to the 2012 National Health Interview Survey (NHIS), the percentage of adults who had seen a doctor in the past 6 months was 66.7 percent for the total population, 60.3 percent for AIAN only, 66.9 percent for whites only, and 78.0 percent for those who reported both white and AIAN as their race. No figures were available for AIAN and black, AIAN and Asian, AIAN and Hispanic or three or more racial/ethnic groups [30]. In general, measures for those who reported AIAN with another race are more like rates for the general US population [3].

One of the biggest factors in determining identification is how to resolve the reporting of multiple races. While the numbers of AIAN are small, whether they reflect AIAN only or AIAN with another race, minor changes can have an outsized impact. Between 2000 and 2010, the number of those who reported AIAN as their only race increased by 18.4 percent and those who reported AIAN with another race rose by 39.2 percent $[3,31]$.

In 2000, of those who reported AIAN as a race, 60.1 percent reported AIAN only and 39.9 percent reported AIAN along with another race. By 2010, 56.2 percent reported AIAN as their only race, while 43.8 percent reported AIAN in conjunction with another race(s) [21]. In both the 2000 and 2010 censuses, the
Table 2

Racial Reporting for those who reported AIAN and Another Race: 2000 and 2010 Censuses

\begin{tabular}{lcc}
\hline & 2000 & 2010 \\
\hline Number & $1,643,345$ & $2,288,331$ \\
AIAN and White & $65.9 \%$ & $62.6 \%$ \\
AIAN and Black & $11.1 \%$ & $11.8 \%$ \\
AIAN, White and Black & $6.8 \%$ & $10.1 \%$ \\
AIAN and Asian & $3.2 \%$ & $2.6 \%$ \\
AIAN and Some Other Race & & $5.1 \%$ \\
AIAN and All Other Combinations & $13.0 \%$ & $7.9 \%$ \\
\hline
\end{tabular}

Sources: Griece, Elizabeth and Cassidy, Rachel; US Census Bureau Overview of Race and Hispanic Origin 2000; C2KBR/01-1; Issued March 2001; Humes, Karen; Jones, Nicholas, and Ramirez, Roberto; US Census Bureau; Overview of Race and Hispanic Origin 2010; C2010BR-02; Issued March 2011.

majority of those who reported AIAN with another race reported White and AIAN [25,26], as shown in Table 2 [26,27].

The best identification algorithm (AIAN alone or AIAN with another race) depends on the purpose of the research. No one measure is better than another. For programmatic and policy purposes relating to federally-recognized Tribes, the designation of AIAN alone (AIAN and no other race) is perhaps best. For purposes of ancestry, the use of AIAN either alone or with other races may be appropriate. Since this paper concerns program research, the use of AIAN as the only race, is used.

The AIAN alone measure is consistent with estimates from the BIA on the population of federallyrecognized Tribes and the service population of the Indian Health Service (IHS). The BIA defines an AIAN person as "... someone who has a blood degree from and is recognized by a federally-recognized tribe or village (as an enrolled Tribal member) ..." According to the BIA's 2013 American Indian Population Labor 
Force Report in 2010, the number of enrolled members in federally-recognized Tribes was 1,969,167 [32] The Indian Health Service provides health care to people who are members in federally-recognized Tribes. In 2014, the IHS service population was estimated to be $2,124,823$. This figure is slightly different from the BIA estimate, because it includes those who reside in an IHS service area (usually on or near Reservations) [33]. Non-AIAN pregnant women can use IHS services if the father is AIAN. Services are also available in case of emergency [33], but these situations contribute little to the overall total eligible for IHS.

While the census did not allow for multiple reporting of races until 2000, the NHIS, sponsored by the National Center for Health Statistics (NCHS), has allowed multiple races since 1982. Models to estimate a single race from multiple races are referred to as bridged estimates. In 2000, the NCHS bridged estimate of the AIAN population was 2,663,818 compared to $2,447,989$ AIAN alone, reported in the 2000 census or about 6.3 percent higher [34].

\section{Statistical issues}

Besides identification issues, the small population and geographical isolation of the AIAN population give rise to many statistical issues. This does not mean that research and analysis cannot be done. It only means that care must be given. The relatively small numbers emphasize the importance of the decennial census. While population-based sample surveys are useful, pooling across multiple years may need to be performed to obtain a sufficient sample size. For variables that change slowly, this can be acceptable. However, for economic characteristics, such as unemployment rates and poverty rates, pooling may not reflect what is going on in real time. In these instances, larger sample sizes (oversampling) and, thus, higher costs may be needed. The National Congress of American Indians (NCAI), the group of Tribal leaders, has described AIAN data as "... the asterisk nation, because an asterisk, rather than a data point, is often used in data displays..." [35].

Small populations (and thus small sample sizes) and numbers mean that break outs by geographical areas like Reservations, Tribes or even by age and gender are typically not possible. We know that unemployment is a major concern for many Tribes, but data cannot be obtained at the Tribal level, so planning or the evaluation of Tribal efforts are almost impossible. While un- employment rates for young adult black men are available and can be used to measure and focus efforts, no such data are available for young male AIANs.

Rates, like those used in such seminal measures as infant mortality rates, are difficult. There are often disagreements about the denominator, how many AIAN people are included and numerators, where data can be unknown or too small to report.

The American Community Survey (ACS) and the NHIS are two of the few large sample surveys. The sampling methods themselves, relying on primary sampling units or PSUs, are more often designed with the general population (not the AIAN population) in mind. PSUs tend to be geographically and municipally based with regards to geographic boundaries by states, counties and cities. The ACS AIAN population estimates, whether using the AIAN only or AIAN and other races measure, are smaller than population estimates from the decennial census. In 2010, the number of those who reported their race as AIAN only was 2,932,248 and the ACS reported in the 2016 the number was 2,676,399 [36]. No explanation for this population decline has been offered, as discussed by Deweaver [37]. It appears that geographical coverage plays a big role. Tribal lands and Reservations tend to be remote and may cross county and state boundaries and regions, which, in turn, results in PSUs being less likely to reflect AIAN geography.

Geographical remoteness and logistics can also be an issue. For example, the National Health and Examination Survey (NHANES) samples Americans to provide information on health and nutrition via physical examinations and personal interviews. Alaska and Hawaii are excluded from the NHANES. In addition, Reservations are not included, resulting in the absence of AIAN estimates from this major nutritional survey.

Differing identification and other statistical techniques make trends difficult to construct. The reliance of surveys on random digit dialing is also problematic, as access to telephones is less among the AIAN population than for the US: the percentage without a telephone was 6.2 percent for AIAN only compared to 3 percent for the entire country [36] in Table 3. Even cell or mobile telephones may be of little use in remote areas where reception is weak or non-existent. Finally, other considerations need to be made. Whereas the US census occurs on April 1, in many remote parts of Alaska, census counts are done in February when the ground is frozen and transportation is easier. Language is also a consideration, as 27 percent of the AIAN people speak a non-English language at home either ex- 
Table 3

Population Profile: American Indians and Alaska Natives (AIAN) and US - 2016

\begin{tabular}{|c|c|c|}
\hline & US & AIAN \\
\hline Total population & $323,127,515$ & $2,676,399$ \\
\hline \multicolumn{3}{|l|}{ 1. Gender } \\
\hline - Percent male & $49.2 \%$ & $49.9 *$ \\
\hline - Percent female & $50.8 \%$ & $50.1 \%$ \\
\hline 2. Median age (in years) & 37.9 & $32.4^{*}$ \\
\hline \multicolumn{3}{|l|}{ 3. Age structure } \\
\hline - Under 18 & $22.8 \%$ & $27.4 \%$ \\
\hline$-65+$ & $15.2 \%$ & $9.8 \% *$ \\
\hline$-75+$ & $6.4 \%$ & $3.4 \% *$ \\
\hline 4. Average household size (in persons) & 2.65 & $3.07 *$ \\
\hline 5. Average family size (in persons) & 3.27 & $3.77 *$ \\
\hline \multicolumn{3}{|l|}{ 6. Families with children } \\
\hline- With related children of the householder $<18$ & $15.9 \%$ & $30.0 \% *$ \\
\hline - With related children of the householder $<5$ only & $15.1 \%$ & $29.7 \% *$ \\
\hline \multicolumn{3}{|l|}{ 7. Educational attainment (aged $25+$ ) } \\
\hline - Less than high school & $12.5 \%$ & $20.1 \% *$ \\
\hline - High school, no college & $27.2 \%$ & $31.6 \% *$ \\
\hline - Some college & $29.0 \%$ & $33.7 \% *$ \\
\hline - Bachelors' degree & $19.3 \%$ & $9.6 \%$ \\
\hline - Graduate degree & $11.9 \%$ & $4.9 \% *$ \\
\hline \multicolumn{3}{|l|}{ 8. Disability (civilian population) } \\
\hline - All ages & $12.8 \%$ & $17.0 \% *$ \\
\hline - Under 18 & $4.3 \%$ & $5.0 \% *$ \\
\hline$-18-64$ & $10.6 \%$ & $17.2 \% *$ \\
\hline \multicolumn{3}{|l|}{ 9. Language spoken at home } \\
\hline - English only & $78.4 \%$ & $73.0 \% *$ \\
\hline - English with other/other only & $21.6 \%$ & $27.0 \% *$ \\
\hline 10. Place of birth in US & $86.5 \%$ & $93.8 \%$ \\
\hline \multicolumn{3}{|l|}{ 11. Poverty rate } \\
\hline - Poverty rate for families & $10.0 \%$ & $21.7 \% *$ \\
\hline - Poverty rate for individuals & $14.0 \%$ & $26.2 \% *$ \\
\hline - Children under 18 & $19.5 \%$ & $33.8 \% *$ \\
\hline$-18-64$ & $13.2 \%$ & $24.0 \% *$ \\
\hline$-65+$ & $9.2 \%$ & $18.8 \% *$ \\
\hline \multicolumn{3}{|l|}{ 12. Labor force participation (aged $16+$ ) } \\
\hline - Employed & $59.1 \%$ & $51.0 \% *$ \\
\hline - Unemployed & $3.6 \%$ & $6.9 \%$ \\
\hline - Not in labor force & $36.9 \%$ & $41,8 \% *$ \\
\hline 16. Unemployment rate & 5.8 & $12.0^{*}$ \\
\hline 17. Median household income & $\$ 57,617$ & $\$ 39,719 *$ \\
\hline 18. Median family income & $\$ 71,062$ & $\$ 47,284 *$ \\
\hline 19. Mean earnings & $\$ 83,372$ & $\$ 58,842 *$ \\
\hline 20. Mean social security income & $\$ 18,656$ & $\$ 14,963 *$ \\
\hline 22. Received food stamps & $12.4 \%$ & $25.0 \% *$ \\
\hline \multicolumn{3}{|l|}{ 23. Health insurance } \\
\hline - Private insurance & $67.8 \%$ & $44.6 \% *$ \\
\hline - Public insurance & $35.4 \%$ & $44.2 \% *$ \\
\hline - No health insurance & $8.6 \%$ & $19.2 \% *$ \\
\hline \multicolumn{3}{|l|}{ 24. Occupied housing unit characteristics } \\
\hline - No telephone & $3.0 \%$ & $6.2 \% *$ \\
\hline - No motor vehicle & $8.7 \%$ & $13.4 \% *$ \\
\hline - More than 1 person per room & $3.4 \%$ & $8.5 \% *$ \\
\hline - 1-unit attached or detached & $68.6 \%$ & $63.9 \% *$ \\
\hline - Mobile home, boat, recreational vehicle, van etc. & $5.6 \%$ & $12.4 \% *$ \\
\hline
\end{tabular}

Source: [17] Selected Population Profile US, 2016 American Community Survey; 1-Year Estimates S0201. Accessed on-line 5/31/2018 Note: *Significance level at or greater than 95\%. 
clusively or with English compared to 21.6 percent for the general population [36].

According to the US Bureau of the Census, the AIAN population (both single race and combined with other races) will grow in numbers and percent of the population until 2060. Although both AIAN populations are projected to grow faster than the overall population, their small percentages will remain small. By 2060 , it is estimated that the AIAN only population will increase from 0.9 percent in 2010 to 1.3 percent in 2060. Similarly, the proportion reporting AIAN along with other races is projected to rise from 0.7 percent in 2010 to 2.4 percent in 2060 [37].

\section{Sociodemographic characteristics}

Although data are limited, AIAN people are unique in many ways as compared to other Americans. In 2016, the ACS reported that for those who reported AIAN only, compared to the US population, AIAN were statistically significantly (95 percent or more) likely to be younger (median age 32.4 compared to 37.9) and more likely to live in a household with related children (30.9 percent compared to 15.9 percent). Socio-economic measures indicated that AIAN people are more likely to live in poverty (26.2 percent compared to 14.0 percent), have a higher unemployment rate (12.0 percent compared to 5.8 percent), have lower median household income $(\$ 47,284$ compared to $\$ 71,062)$, less likely to have health insurance (19.2 percent compared to 8.6 percent), more likely to have a disability (17. 0 percent compared to 12.8 percent), and are less likely to have graduated from high school (20.1 percent compared to 12.5 percent). In addition, AIAN people are less likely to live in an English-speaking only household (73.0 percent compared to 78.4 percent), but more likely to be born in the US (93.8 percent compared to 86.5 percent) [36].

\section{Health characteristics}

This section contains discussions of overall health issues, as well as those pertaining to causes of death and specific health issues of special importance to AIAN people. The IHS is an important source of health care for AIANs, particularly in the area of primary care and prevention. Health care is provided by the IHS for members of federally-recognized Tribes, with facilities typically on or near Reservations. There is a sys- tem of providers covering 12 geographic service areas and comprising most of the 612 IHS and Triballyoperated facilities are located on or near Reservations. The 28 IHS hospitals are not available in all areas and services vary among Tribes. Altogether, about 2.1 million of the 5.2 million AIAN people are eligible for IHS services. Those who are not members of federallyrecognized Tribes or who do not live near IHS facilities have health care and health insurance like most other Americans, either through private insurance, Medicare (if over age 65) or Medicaid if they meet state criteria. There are 41 urban IHS clinics, but they tend to offer far fewer services than those on or near Reservations [33].

\subsection{Vital statistics}

Vital statistics on births and deaths, notably mortality, infant mortality and life expectancy at birth depend on the accuracy of racial identification at the local levels. The records are quite good for those who received care at the IHS, but less so in other facilities. Even with data issues, the health of the AIAN people tends to be worse than for the US population [38]. In 2010, the infant mortality rate (number of deaths of children under the age of one per 1,000 live births) was 8.3 compared to 6.1 for the US [39]. Life expectancy at birth measures from the IHS for the time from 2007-2009 was nearly five years less: 73.7 years for AIAN and 78.5 years in the US [39].

Overall mortality rates in 2016 for all causes were 800.3 per 100,000 population for the AIAN population compared to 728.3 for the US population. AIAN mortality rates were higher for both males and females: 954.0 for AIAN males compared to 861.0 for the US and 668.0 for AIAN females compared to 617.5 for US females. AIAN people had different causes of death. The ratio of leading causes of death (AIAN/US) was about the same $(0.85$ to 1.15$)$ for diseases of the heart, malignant neoplasms, chronic lower respiratory disease, hypertension and pneumonitis. The ratio was higher for accidents (unintentional injuries) at 1.72; diabetes mellitus (2.19), suicide (1.59), chronic liver cirrhosis (3.64) and less likely for Parkinson's" disease (0.54) [40].

\subsection{Suicide}

Mortality rates rise sharply with advancing age, but suicide is highlighted herein, because it is an exception among AIAN people. Suicide mortality rates among 
AIAN people are 60 percent higher compared to the general population [41] and data have shown increasing AIAN suicide rates since 2003 [42]. It is important to note that these data aggregate all AIANs as one large group in the US, painting an erroneous picture that all Tribal communities suffer from suicide-related outcomes when in fact there is large variation by tribe or community [43]. Several studies have shown substantial differences in suicide rates by Tribal community. For example, before implementation of a public health, community-driven and culturally-tailored approach to suicide prevention in the White Mountain Apache Tribe, suicide rates were seven times higher the rate for other AIANs living within IHS service regions and 13 times higher than the suicide rate for the general population [44]. However, other Tribal communities have lower suicide rates. Suicide mortality rates among Native communities located within the Nashville and California Indian Health Service regions are lower than the US general population [45].

There are limitations to various national data sources yielding AIAN suicide statistics. For example, Indian Health Service "Trends in Indian Health Report" [41] provides only statistical data from Tribes and communities receiving programs within specific Indian Health Service regions, leaving out approximately 40 percent of people who identify as AIAN in the US and who do not live within these designated areas. The most recent report on suicide mortality rates among AIANs from the CDC [42] only included AIANs living in 18 states and excluded several states that have the largest AIAN populations in the US according to the Census (e.g., California, Arizona, Texas, New York, Washington, Michigan [46]). Thus, we have access to certain national sources of data with gaps of knowledge as well as locally-gathered and monitored suicide mortality data (e.g., White Mountain Apache Tribe Celebrating Life Suicide Surveillance System [47]), leaving us without comprehensive knowledge of the burden of suicide in AIAN communities.

Despite limitations, existing data that are available highlight important and unique trends within AIAN communities related to suicide. One notable trend includes suicide rates by age among AIAN, which look vastly different from the US general population. Within the US population and all other races, suicide rates increase with age and suicide risk is highest among individuals ages 45 to 65 and older [48]. However, within Native communities, older adults are the most protected group from suicide death and youth are the group most vulnerable. The suicide rate for AIAN youth ages 5 to 14 is approximately six times higher than same-aged peers and among the age group 15 to 24 Native youth die by suicide at rates four times higher. This trend shifts when comparing AIAN suicide mortality rates to US all races rates in the age group 45 to 54 (and older) in which AIAN rates are lower than those in the general population. For example, suicide rates among older adults in the general population aged 55 to 64 are approximately 1.5 times higher the AIAN older adult rate. Similarly, suicide rates among all races US adults aged 85 and older is nearly 2.5 times higher than the AIAN rate for those in the same age group. Overall, the data shows important age trends that AIAN young people are at the highest risk for suicide death, while older age is protective. This information is valuable and can inform suicide prevention and intervention programming within Native communities with particular attention to age.

Tribally-owned data may be a powerful avenue towards tracking trends and developing communitydriven and culturally-informed suicide prevention programs in Native communities. The White Mountain Apache Tribe has collaboratively partnered with Johns Hopkins Center for American Indian Health for more than 30 years on a variety of health issues, including suicide prevention [47]. The White Mountain Apache Tribal Council approved a resolution mandating community-wide suicide surveillance system in 2001 resulting from the community losing several young people to suicide [47]. The Tribal mandate requires reporting of suicide-related outcomes (suicide ideation, attempts, deaths; non-suicidal selfinjury; binge substance use) by all individuals within the community and departments/schools. This surveillance program is managed by the Celebrating Life Team, a group of White Mountain Apache community mental health workers, with technical assistance from Johns Hopkins Center for American Indian Health. When a report is made with the surveillance system, a Celebrating Life team member will conduct a followup visit with the individual to confirm the suiciderelated event, gather additional information (e.g., potential risk and protective factors, past history of mental health disorders and substance use), and assist with connecting the individual to services (including mental health treatment, traditional healing, religious-based counseling, Indian Health Service social services [47]). All forms completed with an individual are entered into a secure, online database. With Tribal ownership of data, the Celebrating Life team with assistance from Johns Hopkins Center for American Indian Health 
can track suicide-related trends over time to inform Tribal leaders and other stakeholders to assist prevention and intervention development [47]. This example highlights the success of one community exercising Tribal sovereignty in suicide-related research and data to understand how suicide is impacting the community and to inform prevention programming. Similar programs implemented throughout Indian Country may have the power to inform community-driven, culturally-informed suicide prevention programs to reduce and ultimately eliminate this inequity [48].

\subsection{Chronic health conditions}

Self-reported health status is a significant indicator for mortality, nursing home admission and hospitalization. In 2012, the NHIS found that the percentage of adults aged 18 or over who reported fair or poor health status (compared to others their age) was 23.1 percent for those who reported AIAN as their only race compared to 12.4 percent for the entire adult population. Current cigarette smoking was not very much higher for AIAN adults (18.8 percent compared to 18.1 percent) than for the US population, but AIAN adults were less likely to currently and regularly drink alcohol: 40.8 percent compared to 51.6 percent. AIAN adults were less likely to have visited the doctor in the last twelve months than the US population: 27.5 percent and 20.4 percent, respectively [31].

Chronic health problems are of significant concern among AIAN people, as they lead to increased morbidity, mortality and disability. Today, the major cause of death among AIANs is cancer followed by heart disease [49]. Cardiovascular/heart disease, cancer and obesity are chronic illnesses that are the major causes of poor health status among AIANs. Specific health problems have changed from the acute to chronic conditions over the past several decades. Type 2 diabetes was first documented among American Indians in the early 1960s [50].

\subsection{Cancer}

The CDC reported that American Indians and Alaska Natives have unique cancer patterns due largely to their history and culture, whether they live on Reservations or urban areas, and how they get health care [50]. Cancer rates can vary by region, however, the CDC reports that for all areas in the US, the five most common causes of cancer deaths among AIAN men were lung, colon and rectum, prostate, liver, and kidney [51].
Likewise, the five most common causes of cancer death among AIAN women were reported to be lung, breast, colon and rectum, pancreas, and ovary [51].

One factor associated with the reported cancers among AIANs is the high rate of cigarette smoking among both men and women. In addition, although rates have decreased from the extreme high of 50 percent reported two decades ago to the present range of 20-40 percent [52], smoking cessation programs have had very little effect on some Tribal groups. Hodge and others [53] reported lenient behaviors and the preference for branded cigarettes among some AIAN groups. Cigarette smoking is an addiction that requires targeted intervention and culturally appropriate prevention programs.

A high rate of cervical cancer among American Indian women may be due to the human papillomavirus (HPV). The human papillomavirus, four of which are associated with 99 percent of cervical cancers, is documented to be widely prevalent in American Indian populations [54]. Currently, vaccinations are available to protect against HPVs, however, recommended protocols that targets adolescents and young adults - ages 9-26, coupled with poor vaccine compliance in this population, results in higher risk for cervical cancer. HPV is highly associated with cervical, and oral mucosal pathologies also associated with the human papillomavirus (HPV) and/or the use of tobacco products [54]. Two vaccines (Gardasil and Cervarix) guard against several types of the virus and are recommended for males and female youth and young adults (ages 1226) [55]. Low levels of knowledge about the HPV virus and fears of inoculation have had a prohibited effect on acceptance of the vaccination [56]. The two-shot vaccine would protect females from cervical cancer, however, fears and cultural-related factors reported in studies need to be better understood in order to improve vaccination rates [57].

\subsection{Alcohol use}

Substance use among American Indians and Alaska Natives is complex. National trends are similar for $\mathrm{Na}$ tive and non-Native youth [58,59]; however, substance use rates are consistently higher for American Indian (AI) youth compared to White adolescents, especially for alcohol and marijuana [59-61]. The most recent large national surveys of cross-racial alcohol/drug use have indicated especially high binge drinking rates for AIANs [60-62,64]. Furthermore, AIAN people have the largest health disparities in alcohol-related morbid- 
ity and mortality of all racial and ethnic groups in the US, including from violence, motor vehicle accidents and suicide $[65,66]$.

American Indian and Alaska Native adolescents are most at risk. AIAN adolescents report the highest rate of past month binge drinking (14.1 percent) versus other racial and ethnic groups [60] and are more likely than Whites to indicate lifetime alcohol use (73.5 percent vs. 63.9 percent), past 30-day use (63.4 percent vs. 56.3 percent), and past 30-day heavy episodic use (46.9 percent vs. 35.5 percent) [68]. Importantly, Native youth are at greater risk for early initiation $[63,68]-$ the odds of alcohol misuse more than double each year between ages 10 and 15 for AIs [63,67]. Initiation of alcohol use before age 13 increases the likelihood of future alcohol abuse and dependence [69,70]. Alcohol misuse behaviors were previously concentrated among Native boys [67]; however, Native girls appear to be initiating drinking earlier and increasingly affected [63,71-74].

While average rates of AIAN substance use are high, there appear to be divergent trajectories over time with Native youth either developing patterns of: 1) no or low use, 2) alcohol misuse, and 3) potential dependence. Native adolescents who engage in alcohol misuse are more likely to continue these behaviors into early adulthood, develop substance use disorders, and have behavioral and mental health impacts $[67,75,76]$. A prospective, longitudinal study that followed a sample of $\sim 600$ AIAN adolescents for 8 years gives the most definitive information on substance trajectories, comorbid disorders and outcomes. Seventy percent of those who initiated alcohol use before age 13 and 50 percent of those who started at age 13 or after met abuse or dependence diagnostic criteria by ages 15 17 [71]. Over half had a mental or substance use disorder in their lifetime, and over a third had two or more disorders in young adulthood [71], with males more likely to meet Conduct Disorder criteria (30.9 percent vs. 17.7 percent) and females more likely to meet Major Depressive Disorder criteria (12.8 percent vs. 6.2 percent) [75].

National datasets have shown that AIAN people were more likely to have needed and received treatment for alcohol use than other racial and ethnic groups among those ages 12 and over (14.4 percent vs. 7.6 percent from other racial/ethnic groups). The Treatment Episode Data Set (TEDS) indicates there were approximately 44,000 substance abuse treatment admissions, 2.5 percent of the total admissions, for this population in 2012 [77].
Consistent with earlier data, 17.3 percent of AIANs who were admitted began using substances at age 11 or younger compared to 10 percent of other admissions. Among those who did not receive services, 4.3 percent of AIANs, expressed the need for, and tried to get treatment compared to 1.5 percent of those from other racial and ethnic groups. Furthermore, a higher percentage of AIANs adult admissions are referred by the criminal justice system ( 45.9 percent vs. 35.8 percent), yet a lower percentage are referred by individuals or self-referred ( 22.5 percent vs. 34.7 percent), than other adult admissions [78].

An overlooked strength is that many AIAN adolescents and adults abstain from alcohol use [74,79]. In the longitudinal study cited above, 64 percent of adolescents reported abstaining from alcohol use up to age 14 [71]. Native adults had the lowest rate of past month alcohol use (37.1 percent) of all racial and ethnic groups [80]. Furthermore, several studies show higher rates of lifetime abstainers and former drinkers, as well as lower rates of current drinkers, across different Tribal groups in comparison to general US data $[63,81,82]$. In summary, given abstinence rates range from 60 percent- 70 percent $[74,79]$, it may be that there is less drinking overall but the amount and consequences are more severe in AIAN than in the general population.

\subsection{Obesity}

An obesity epidemic has been reported among American Indians for the last three to four generations. Today, the obesity prevalence rates reported for many Tribal groups far exceed that of the general population $[83,84]$. National health profiles reports that AIAN adults are 1.6 times more likely than White adults to be obese $[83,85]$. AIAN obesity has alarmingly escalated to a high of 40-60 percent within certain Tribes [85]. This has resulted in various studies seeking to ascertain cause or factors contributing this excess weight gain $[86,87]$. One explanation has focused on the effects of cultural transitions from traditional ways of life to modern day lifestyles [88], leading to insights about disparities among AIAN people. The influence of historical traumas, geographical isolation, and lack of resources has had a profound effect on health disparities.

Over the past decades, movement from traditional ways of life to more modern lifestyles have been repeatedly referenced as one of the key contributors to obesity among AIANs [89-91]. Rugged daily activities and traditional foods often dependent on seasonal 
and natural resources, have slowly changed to more sedentary day-to-day activities and the ready availability of processed foods. Epigenetic theories have postulated that obesity will increase among AIANs with complications of type 2 diabetes and cardiovascular disease [87,92]. Researchers have approached the public health problem of obesity with programs that propose education coupled with diet and exercise activities [91,92]. Various interventional trials promoting behavior change have been conducted in AIAN communities to prevent and mitigate health consequences associated with obesity. However, problems related to obesity, such as type 2 diabetes, cardiovascular disease, dyslipidemia, joint and mobility problems and early death continue unabated. The interventional studies have reported only moderate successes in their attempts to modify food selection, dietary intake volume, and exercise among AIAN people utilizing cultural traditions [93,94]. However, these behavioral modification trial have not proven highly successful [90].

Recent studies have highlighted and between obesity and a history of trauma or adverse events in childhood [95,96]. Hodge [97] has reported an association between obesity and childhood trauma. Her study assessed the association between several reported experiences of abuse associated in childhood (physical, mental, verbal and sexual). Verbal abuse experienced among American Indians in childhood proved to be highly associated with adult obesity.

\section{Special populations}

Population-based surveys, like the NHIS-D, the Current Population Survey and the ACS report data on poverty, unemployment rates and health status. However, these surveys are limited to the civilian noninstitutionalized population. They do not cover those who are homeless or incarcerated. Other special populations, such as AIAN children in foster care, are a small part of a small AIAN population. AIAN people are in foster care, incarcerated or homeless are a very small part of a small population. Data are hard to obtain, but are needed, because AIAN people tend to be overrepresented in these special populations.

\subsection{Foster care}

Historically, Native Americans were over-represented among children in foster care. Until 1978, when Congress passed the Indian Child Welfare Act to end "a pattern of discrimination against American Indians", an estimated 25 percent to 30 percent of Native American children had been removed from their families [98]. By 1999, Native American children accounted for only one percent of children in foster care. Despite this, American Indian and Alaska Native children are placed into foster care at a rate 2.7 times greater than their proportion in the general population Nationwide, according to the National Indian Child Welfare Association (NICWA) [99].

The Indian Child Welfare Act (ICWA) of 1978 is a federal law that governs the removal and out-of-home placement of eligible American Indian children who are in the state's custody [100]. More recently, concerns have arisen with regard to placement of American Indian children into non-Indian homes, which may facilitate the loss of native languages, customs, and culture. The lack of American Indian foster homes may be due to Reservation sites being located in rural areas, far from needed health and education resources, and the lack of knowledge in American Indian communities about the need for foster homes.

States have the responsibility to identify American Indian children once they are involved in state custody, due to loss of parents, accidents and other factors. Once identified as an American Indian, the specific Tribe and location of the Tribal community needs to be identified so that notification can be sent to the Tribe. Once notified, the Tribe then has the right to assume custody of the child(ren) and to place the child with relatives or other members of the Tribe. Problems arise with the child is not knowledgeable of their Tribal history, and notification of the Tribe is stalled. Gathering data on the background and Tribal affiliation of the child may be lengthy, as many are members of several Tribes, or their parents may have lived away from the Tribe for many years and have lost contact with the Tribe. In addition, the legal and housing cost to the Tribe may be high, resulting in decisions to allow the state to place the child in foster care. Foster home children face many obstacles in their life including identify issues, loss of extended family and their Tribal culture. In addition, although the ICWA legislation is meant to assist in resolving these issues, complex problems arise and children may never be placed in American Indian homes.

\subsection{The criminal justice system in Indian Country and the incarcerated}

Jurisdiction in the criminal justice system is very confusing in Indian Country. It is determined by a 
number of factors including location of the crime (Native land or not), the type of crime committed (felony or misdemeanor), the status of the perpetrator (Native or non-Native), and whether the Tribe qualifies for special domestic violence criminal jurisdiction [15]. Further, as discussed above, determining whether an individual is a Native in and of itself can be challenging and subjective due to the fact that there are many people with mixed heritage and because classification could be determined by a number of factors including blood quantum, self-identification, and membership in a federally-recognized Tribe [15].

Due to the relationship of Native Tribes to the federal government, Natives who are convicted of certain crimes within Indian Country under the Major Crimes Act are subject to harsher sentences than the general population. This is because they are subject to federal (as opposed to state) laws, which tend to be more severe [101]. This includes offenses that are almost exclusively within states' criminal jurisdiction, such as manslaughter, assault, and sex offense [102]. Therefore, because of their status as AIAN, Natives face disproportionately harsher sentences than their nonAIAN counterparts.

Double sentencing is another major concern for AIAN people who are convicted of crimes, meaning that they are subject to laws and sentencing in both the Native community (under Tribal law) and under federal law. This is a result of the US Constitution, the Indian Civil Rights Act, the Supreme Court's decisions on the issue, and subsequent legislation [102]. These policies essentially expose AIANs to double jeopardy and allows them to be tried, convicted, and sentenced twice for the same crime, while other Americans are protected against double jeopardy by Fifth Amendment to the United States Constitution [103].

High incarceration rates are a major concern for AIANs whereas Natives are far overrepresented in US jails and prisons with a rate 38 percent higher than national average incarceration rate [104]. AIAN people are incarcerated at a rate of 895 per 100,000 , while their white counterparts experience an incarceration rate of 450 per 100,000 [105]. Criminal justice policies and laws that negatively impact AIANs, including the fact that they experience harsher sentencing because they are subject to federal prosecution for serious crimes committed on Reservations contribute to this phenomenon [106]. In fact, between 2011 and 2015, the number of AIANs incarcerated in federal prisons increased by 27 percent [104]. AIAN men are incarcerated at a rate four times that of white men in the United State [104]. While AIAN males represent the largest portion of the inmate population in Indian Country, the percentage of female inmates increased from 20 percent to 24 percent of all inmates from 2000 to 2014 [107]. AIAN women are incarcerated at a rate six times the rate of white women [104]. AIAN people fall victim to violent crime at a rate that is more than double the rate of all other Americans with 88 percent of violent crime committed against AIAN women being carried out by non-Native perpetrators [104].

\subsection{Homelessness}

People can be homeless for a short or long periods of time. The homeless population is defined as "... those without a fixed, regular, adequate nighttime residence", according to the Department of Housing and Urban Development [108]. As of January 2016, there were nearly 550,000 homeless individuals, of whom about 15,000 were AIAN. While the number of homeless people has been decreasing in recent years, this has not been the case for AIAN people [108]. Homeless people live in shelters or other quarters (i.e. the sheltered homeless) or on the street (i.e. the unsheltered homeless) [108]. AIAN homeless individuals are more likely to be unsheltered than the total homeless population: 48 percent compared to 32 percent. The same pattern is shown for homeless individuals (60 percent vs 44 percent), homeless families (16 percent vs 10 percent) and homeless veterans (54 percent vs 33 percent) [108].

\section{Emerging issue - murdered and missing indigenous women and girls}

An emerging issue for the US, but an old issue for AIAN communities, is murdered and missing Indigenous women and girls. Perhaps there is no other issue, which illustrates the adverse effects of societal and statistical invisibility. It is estimated that every year in North America, hundreds of Indigenous Women go missing or are found murdered, but finding an exact number is nearly impossible due to under-reporting by local police, lack of tracking by the Federal Bureau of Investigation, and lack of academic research on the subject. Although this issue has been prominent in AIAN communities in the US for many years, it has not been visible in the national dialogue until very recently. 
Similar issues exist across the border in Canada. The Canadian government released the results of an ongoing investigation into the disappearance of Indigenous women in 2014 but have run into similar issues of under reporting by local law enforcement [109]. Reports from the Canadian government estimated the number of missing and murdered Indigenous women and girls to be 1,200 missing Indigenous women between the 1980 and 2012; however, the number may be closer to 4,000 [109].

In the US there were 5,712 cases of missing $\mathrm{Na}$ tive women reported to the National Crime Information Center in 2016. The lack of data is so serious that Annita Luchesse, an independent doctoral student had to build her own database [110] to track publicly reported missing or murdered Indigenous women in the US and Canada.

The question remains: why are Indigenous women going missing? The answer may lie in the rate of violence against Indigenous women. The National Institute of Justice found in a recent study found that of the Indigenous women surveyed, four out of five of them (83 percent) had experienced violence in their lifetime, 1.2 times the rate for non-Hispanic white women. Nearly 40 percent of AIAN women experienced violence during 2016. AIAN men are also much more likely to experience violence ( 81.6 percent) in their lifetimes compared to 64 percent of non-Hispanic White men [111].

Jurisdictional issues, mentioned earlier, complicate what happens when a woman or girl becomes missing. It may take much longer before law enforcement become involved. Human trafficking may account for a portion of these missing women, especially in states like North Dakota that have a booming oil business [112]. While not much can be ascertained from the limited data on these missing women, what's clear is that we need more study and policy making to address the problem. The recent election of the first two AIAN women to the US Congress may promise to bring this and other issues into the national dialogue.

\section{Conclusion}

Identification, that is, how we define who is an American Indian or Alaska Native, is the foundation of good reliable data. Results vary depending on who we are talking about and who we are analyzing.

Even with limited data, we know that there are disparities between basic socio-demographic, economic and health characteristics between American Indian and Alaska Natives and the US population. Closing these gaps and addressing program and policy issues is complicated by the invisibility of American Indians and Alaska Natives in their own land. It is not clear if invisibility results from lack of data or if lack of data leads to invisibility.

Statistics reflect real people and their stories. Data are compiled to present a picture of what is happening in our communities. Statistics tell our stories and keep them alive. The lack of good data about American Indians and Alaska Natives can no longer be dismissed as so difficult that we shouldn't even try. There are major concerns, such as small population sizes and geographical isolation, but there are solutions. Data could be collected and special studies could be performed if resources were made available.

Data can help. For example, the monthly unemployment rate is not reported for AIAN people, due to small sample sizes. If unemployment rates were known nationally or at local levels, targeted employment programs could be more effective and many problems from unemployment and poverty could be alleviated.

Data is needed on the total American Indian and Alaska Native population and on subpopulations, such as women, adolescents, or people residing in particular Reservations or regions. We also cannot ignore special populations, such as foster children, the homeless and the incarcerated. They are small parts of a small population, but critical because they are overrepresented in Native communities.

American Indians and Alaska Natives, like other Americans, must be included in discussions of policy, programs and legislation. Discussions will be easier with data. Data will enable American Indians and Alaska Natives to tell our own stories in our own way and show that we are unique and that we are still here. The invisibility of American Indians and Alaska Natives in their own country needs to end and end now.

\section{Acknowledgments}

We wish to thank our supporters from the International Group for Indigenous Health Measurement (IGIHM), in particular, Sam Notzon, the IGIHM cochair. The three US members of the IGIHM Identification working group (Michele Connolly, Bette Jacobs and Felicia Hodge) are co-authors of this paper. We also thank the other members for their unflagging support and willingness to share: Clare Coleman, Kalinda Griffiths, John Waldon, and Alexandra King. 
The authors would not be here without the love and sacrifice of our ancestors who kept our people, traditions and culture alive. We thank them.

This paper is dedicated to all our relations in past, present and future generations. Of special note is Ashley Loring-Heavy Runner of the Blackfeet Nation, who as of this writing, is still missing.

\section{References}

[1] Connolly M. Improving lives of Indigenous people through better statistics: meeting policy and program needs. $16^{\text {th }}$ Conference of IAOS, OECD Headquarters, Paris France. September 2018.

[2] Office of the Federal Register. Indian entities Recognized and Eligible to Receive Services from the United States Bureau of Indian Affairs. Federal Register. 2018; 83(20).

[3] US Census Bureau. The American Indian and Alaska Native Population: 2010; C2010BR-10. Washington, DC. February 2012.

[4] U.S. Census Bureau. The Native Hawaiian and Other Pacific Islander Population: 2010. C2010BR-12. Washington DC. May 2012.

[5] Bird M. Public Health Post. August 20, 2018.

[6] First Nations Development Institute, Reclaiming Native Truth, Research Findings: Compilation of all Research. Denver, Colorado; June 2018.

[7] Jobe M. Native Americans and the US Census: A Brief Historical Survey University Libraries Faculty and Staff Contribution. 2004; 28.

[8] Tyler SL. A History of Indian Policy. US Department of Interior; Washington DC, 1973. 1975.

[9] The Constitution of the United States. Article 1, Section 8. Clause 3.1789

[10] Gilio-Whitaker Dina. Injustices of the Past and Present in Indian Country: Ways the Past Sill Works against Native Americans. Thought Co., (last updated Oct. 09, 2017), available at https://www.thoughtco.com/injusticesof-the-past-and-present-4082434 (last visited June 6, 2018).

[11] The Constitution of the United States. Article II, Section 8 . Clause 2. 1789.

[12] Department of Veterans' Affairs. America's Wars. Office of Public Affairs. Washington, DC. Accessed at http://www.va. gov/opa/publication/factsheets/fs_americas_wars.pdf.

[13] McPherson Robert. History of San Juan County. http://utah humanities.org/stories/items/show/103.

[14] Palmer J, Chino M. (in press). Violence in American Indian and Alaska Native communities. In C.A. Cuevas and C.M. Rennison (Eds.). The Wiley-Blackwell Handbook on the Psychology of Violence. West Sussex, UK: WileyBlackwell. P. 6. Accessed at: https://www.american.edu/spa/ faculty/upload/palmerchino_inpress_2014.pdf.

[15] Butts J. Note, Victims in Waiting: How the Homeland Security Act Falls Short of Fully Protecting Tribal Lands, 28 AM. INDIAN L. REV. 373, 375-76 (2003-2004). The three cases that comprise "The Marshall Trilogy" are Johnson $v$ McIntosh, 21 U.S. (8 Wheat.) 543 (1823), Cherokee Nation, 30 U.S. (5 Pet.) 1, and Worcester v. Georgia, 31 U.S. (6 Pet.) 515 (1832).

[16] Cherokee Nation v. State of Ga., 30 U.S. 1, 14 (1831).

[17] Worcester, 31 U.S. (6 Pet.) at 561.
[18] United States v. Rogers. 45 U.S. (4How.) 567, 572 (1846).

[19] United States v. Kagama. 118 U.S. 375, 384 (1886).

[20] United States v. Antelope. 430 U.S. 641, 648 (1977).

[21] US Department of Interior. Bureau of Indian Affairs. Accessed at https://www.bia-gov/frequently-asked-questions.

[22] Connolly Michele. Trends in US census counts on American Indians and Alaska Natives. Workshop: Review of ABS standard Indigenous identification questions. Sydney Australia, November 27, 2013.

[23] The Constitution of the United States. Article I, Section 2. Washington DC, 1789.

[24] US Census Bureau. Historical statistics of the United States, Colonial Times to 1970, Bicentennial Edition, Volumes 1 and 2; Washington, DC, 1975.

[25] US Census Bureau. American Indians, Eskimos and Aleuts on Identified reservations and in the historic areas of Oklahoma; PC80-2-1D; Washington DC, Issued January 1986.

[26] Griece E, Cassidy R. US Census Bureau. Overview of Race and Hispanic Origin 2000. C2KBR/01-1; Issued March 2001.

[27] Humes Karen, Jones N, Ramirez R. US Census Bureau; Overview of Race and Hispanic Origin 2010; C2010BR-02; Issued March 2011.

[28] AncestryDNA ${ }^{\mathrm{TM}}$. DNA tests for ethnicity and genealogy DNA test. Accessed at http://www.ancestry.com/dna/.

[29] AncestryDNA ${ }^{\mathrm{TM}}$. Ethnicity estimate 2018 white paper. Accessed at http://www.ancestry.com/dna/.

[30] Blackwell D et al., Summary Health Statistics for US Adults: National Health Interview Survey, 2012; Vital and Health Statistics, Series 10, Number 260; February 2014.

[31] Ogunwole Stella. US Census Bureau, The American Indian and Alaska Native population: 2000, C2KBR/01-15. Washington, DC. February 2002.

[32] US Department of the Interior. 2013 American Indian Population and Labor Force Report. January 2014.

[33] Congressional Research Service. The Indian Health Service (IHS): An Overview. January 2016.

[34] Ingram DD et al. United States census 2000 population with bridged race categories. National Center for Health Statistics, Vital Health Stat 21 (135); Hyattsville MD; September 2003.

[35] National Congress of American Indians. http://www.ncai. org/policy-research-center/research-data/data.

[36] Selected Population Profile US, 2016 American Community Survey; 1-Year Estimates S0201. Accessed on-line 5/31/ 2018.

[37] National Congress of American Indians (Deweaver); http:// www.ncai.org/policy-research-center/initiatives/ACS13RER-1_ACS_Coverage.pdf.

[38] US Bureau of the Census, Population Division; Tables 10 (Projections of the Population by Sex, Hispanic Origin and Race for the US: 2015 to 2060) and 11 (Percent Distribution of the Projected Population by Sex, Hispanic Origin and Race for the US: 2015 to 2060). December 2014.

[39] Anderson I, Robson B, Connolly M, Al-Yaman F et al. Indigenous and Tribal peoples' health (The Lancet-Lowitja Institute Global Collaboration): a population study. Lancet (London, England). 2016; 388(10040): 131-57.

[40] Heron Melonie,"Deaths: Leading Causes for 2016"; National Vital Statistics Reports; Vol. 67 no. 6; Hyattsville MD; July 26, 2018

[41] Indian Health Service (2014). Trends in Indian Health 2014 Edition. Rockville, MD: Public Health Service, U.S. Department of Health and Human Services. 
[42] Leavitt RA, Ertl A, Sheats K, Petrosky E, Ivey-Stephenson A, Fowler KA. Suicides among American Indian/Alaska Natives - National Violent Death Reporting System, 18 states, 2003-2014. MMWR Morbidity and Mortality Weekly Report. $2018 ; 67(8): 237-242$.

[43] Wexler L, Chandler M, Gone JP, Cwik M, Kirmayer LJ, LaFromboise T, Brockie T, O'Keefe V. Walkup J, Allen J. Advancing suicide prevention research with rural American Indian and Alaska Native populations. American Journal of Public Health. 2015; 105(5): 891-899. doi 10.2105/AJPH.2014.302517.

[44] Mullany B, Barlow A, Goklish N, Larzelere-Hinton F, Cwik M, Craig M, Walkup JT. Toward understanding suicide among youths: Results from the White Mountain Apache Tribally mandated suicide surveillance system, 2001-2006. American Journal of Public Health. 2009; 99(10): 18401848. doi: http://dx.doi.org/10.2105/AJPH.2008.154880.

[45] Indian Health Service (2012). Regional Differences in Indian Health 2012 Edition. Rockville, MD: Public Health Service, U.S. Department of Health and Human Services.

[46] Norris T, Vines PL, Hoeffel EM. (2012). The American Indian and Alaska Native population: 2010. Retrieved from http://www.cen-sus.gov/prod/cen2010/briefs/c2010br10.pdf.

[47] Cwik MF, Barlow A, Goklish N, Larzelere-Hinton F, Tingey L, Craig M, Lupe R. \& Walkup J. Community-based surveillance and case management for suicide prevention: An American Indian Tribally initiated system. American Journal of Public Health. 2014; 104(Suppl 3): e18-23. doi: 10.2105/ AJPH.2014.301872.

[48] Suicide Prevention Resource Center (2018). Suicide by Age. Retrieved from: https://www.sprc.org/scope/age.

[49] Centers for Disease Control. Health Disparities in Cancer. Disparities among American Indians and Alaska Natives https://www.cdc.gov/cancer/healthdisparities/what_cdc_is_ doing/aian_faq.htm.

[50] Bennett PH, Burch TA, Miller M. Diabetes mellitus in American (Pima) Indians. Lancet. 1971; 2(7716): 125-128.

[51] Centers for Disease Control. Health Disparities in Cancer Disparities among American Indians and Alaska Natives. https://www.cdc.gov/cancer/healthdisparities/what_cdc_is_ doing/aian.htm.

[52] California Health Interview Survey (CHIS). 2011-2014, Center for Health Policy Research, University of California, Los Angeles.

[53] Hodge F, Struthers R. Persistent smoking among Northern Plains Indians: lenient attitudes, low harm value and partiality towards cigarette smoking. Journal of Cultural Diversity. 2006; 13(4): 181-185.

[54] Lee K, Saralya M, Thompson TD, Chesson HW, Markowitz LE, Kim JJ. Racial and ethnic disparities in human papillomavirus associated cancer burden with first generation and second-generation human papillomavirus vaccines. Cancer. July 1. 2016; 122(13)

[55] National Cancer Institute, Fact Sheet. Human Papillomavirus (HPV) Vaccines 12/27/11. http://www.cancer.gov/ cancertopics/factsheet/Prevention/HPV-vaccine.

[56] Itty TL, Hodge F, Poitra CM, Cardoza B. HPV awareness among American Indian young adults: Implications for health education in adolescents. Journal of Cultural Diversity. 2012; 21(4): 123-129.

[57] Hodge F. American Indian male college students' perception and knowledge of human papillomavirus. Journal of
Vaccine and Vaccination. 2014; 5(2): doi: 10.4172/21577560.1000222

[58] Beauvais F, Oetting ER. Variances in the etiology of drug use among ethnic groups of adolescents. Public Health Rep. 2002; 117(Suppl 1): S8-14.

[59] Beauvais F, Jumper-Thurman P, Helm H, Plested B, Burnside M. Surveillance of drug use among American Indian adolescents: Patterns over 25 years. Journal of Adolescent Health. 2004; 34(6): 493-500. http://dx.doi.org/10. 1016/j.jadohealth.2003.07.019

[60] Chen HJ, Balan S, Price RK. Association of contextual factors with drug use and binge drinking among white, Native American, and mixed-race adolescents in the general population. Journal of Youth and Adolescence. 2012; 41(11): 1426-1441. http://dx.doi.org/10.1007/s10964-012-9789-0.

[61] Miller KA, Stanley LR, Beauvais F. Regional differences in drug use rates among American Indian youth. Drug and Alcohol Dependence. 2012; 126(1-2): 35-41. Accessed http://dx.doi.org/10.1016/j.drugalcdep.2012.04.010.

[62] Stanley LR, Harness SD, Swaim RC, Beauvais F. Rates of substance use of American Indian students in 8th, 10th, and 12th grades living on or near reservations: Update, 20092012. Public Health Reports (Washington, D.C.: 1974). 2014; 129(2): 156-163.

[63] Walls M, Sittner Hartshorn KJ, Whitbeck LB. North American indigenous adolescent substance use. Addictive Behaviors. 2013; 38(5): 2103-2109. http://dx.doi.org/10.1016/ j.addbeh.2013.01.004.

[64] Whitbeck LB, Armenta BE. Patterns of substance use initiation among indigenous adolescents. Addictive Behaviors. 2015; 45: 172-179. http://dx.doi.org/10.1016/j.addbeh. 2015.01.006

[65] Chartier K, Vaeth P, Caetano R. Focus on: Ethnicity and the social and health harms from drinking. Alcohol Research Current Reviews. 2013; 35(2): 229-237.

[66] Chen CM, Dufour MC, Yi H-Y. Alcohol consumption among young adults ages 18-24 in the United States: Results from the 2001-2002 NESARC survey. Alcohol Research \& Health. 2004-2005; 28(4): 269-280.

[67] Friese B, Grube JW, Seninger S, Paschall MJ, Moore RS. Drinking behavior and sources of alcohol: Differences between Native American and white youths. Journal of Studies on Alcohol and Drugs. 2011; 72(1), 53-60. http://dx.doi.org/10.15288/jsad.2011.72.53.

[68] Walls ML, Whitbeck LB, Hoyt DR, Johnson KD. EarlyOnset Alcohol Use Among Native American Youth: Examining Female Caretaker Influence. Journal of Marriage and Family. 2007; 69: 451-64.

[69] Grant BF, Dawson DA. Age at onset of alcohol use and its association with DSM-IV alcohol abuse and dependence: results from the national longitudinal alcohol epidemiologic survey. Journal of Substance Abuse. 1997; 9: 103-10.

[70] Hawkins JD, Graham JW, Maguin E, Abbott R, Hill KG Catalano RF. Exploring the effects of age of alcohol use initiation and psychosocial risk factors on subsequent alcohol misuse. Journal of Studies on Alcohol. 1997; 58: 280-90.

[71] Cheadle JE, Whitbeck LB. Alcohol use trajectories and problem drinking over the course of adolescence: A study of North American indigenous youth and their caretakers. Journal of Health and Social Behavior. 2011; 52(2), 228-245.

[72] Heavyrunner-Rioux AR, Hollist DR. Community, family, and peer influences on alcohol, marijuana, and illicit drug use among a sample of Native American youth: An analysis of predictive factors. Journal of Ethnicity in 
Substance Abuse. 2010; 9(4): 260-283. http://dx.doi.org/ $10.1080 / 15332640.2010 .522893$

[73] Walls M, Sittner Hartshorn KJ, Whitbeck LB. North American indigenous adolescent substance use. Addictive Behaviors. 2013; 38(5): 2103-2109. http://dx.doi.org/ 10.1016/j.addbeh.2013.01.004

[74] Whitesell NR, Asdigian NL, Kaufman CE et al. Trajectories of substance use among young American Indian adolescents: Patterns and predictors. Journal of Youth and Adolescence. 2014; 43(3): 437-453. http://dx.doi.org/10.1007/s10964-013 $-0026-2$.

[75] Whitbeck LB, Sittner Hartshorn KJ, Crawford DM, Walls ML, Gentzler KC, Hoyt DR. Mental and substance use disorders from early adolescence to young adulthood among indigenous young people: Final diagnostic results from an 8-year panel study. Social Psychiatry and Psychiatric Epidemiology. 2014; 49(6), 961-973. http://dx.doi.org/10.1007/s00127-014-0825-0.

[76] Whitesell NR, Beals J, Mitchell CM, Spicer P, Novins DK, Manson SM, AI-SUPERPFP Team. Disparities in drug use and disorder: Comparison of two American Indian reservation communities and a national sample. The American Journal of Orthopsychiatry. 2007; 77(1), 131-141. http://dx.doi.org/10.1037/0002-9432.77.1.131.

[77] Substance Abuse and Mental Health Services Administration. The TEDS Report: American Indian and Alaska Native Substance Abuse Treatment Admissions are More Likely Than Other Admissions to Report Alcohol Abuse. Rep 2014.

[78] Substance Abuse and Mental Health Services Administration, Center for Behavioral Health Statistics and Quality. The NSDUH Report: Need for and Receipt of Substance Use Treatment among American Indians or Alaska Natives. 2012.

[79] Pemberton MR, Colliver JD, Robbins TM, Gfroerer JC. Underage alcohol use: Findings from the 2002-2006 National Surveys on Drug Use and Health. (DHHS Publication No. SMA 08-4333, Analytic Series A-30). Rockville, MD: Substance Abuse and Mental Health Services Administration, Office of Applied Studies, 2008.

[80] Substance Abuse and Mental Health Services Administration. Results from the 2009 National Survey on Drug Use and Health: Volume I. Summary of National Findings. NSDUH Series H-38A, HHS Publication No. SMA 10-4856. Rockville, MD: SAMHSA Office of Applied Studies 2010.

[81] Mitchell CM, Beals J, Whitesell NR, The Voices of Indian Teens and Pathways of Choice Teams. Alcohol use among American Indian high school youths from adolescence and young adulthood: a latent Markov model. J Stud Alcohol Drugs. 2008; 69(5): 666-675.

[82] Beals J, Spicer P, Mitchell CM, Novins DK, Manson SM, AI-SUPERPFP Team. Racial disparities in alcohol use: comparison of 2 American Indian reservation populations with national data. American Journal of Public Health. 2003; 93(10): 1683-1685.

[83] Barnes PM, Adams PF, Powell-Griner E. Health characteristics of the American Indian and Alaska Native adult population. United States 2004-2009. National Health Statistics Report no. 20. USDHHS. Hyattsville, MD. National Center for Health Statistics.

[84] Barnes PM, Adams PF, Powell-Griner E. Health characteristics of the American Indian and Alaska Native Adult Population: United States, 1999-2003 Advance Data no 356. USD-
HHS. Hyattsville, MD: National Center for Health Statistics, 2005.

[85] Story M, Evans M, Fabsitz RR, Clay TE, Holy Rock B et al. The epidemic of obesity in American Indian communities and the need for childhood obesity-prevention programs. American Journal of Clinical Nutrition. 1999; 69: 747S-754S.

[86] Halpern P. Obesity and American Indian/Alaska Natives, Office of Assistant Secretary for Planning \& Evaluation, DHHS. 2007.

[87] Lindsay RS, Cook V, Hanson RL, Salbe AD, Tataranni Aet al. Early excess weight gain of children in the Pima Indian population. Pediatrics. 2002; 109: E33.

[88] Byrne KB, Parris DC. Reconstruction of the diet of the Middle Woodland Amerindian population at Abbott Farm by bone trace-element analysis. American Journal of Physical Anthropology. 1987; 74: 373-384.

[89] Rhoades ER, Hammond J, Welty TK, Handler AO, Amler $\mathrm{RW}$. The Indian burden of illness and future health interventions. Public Health Rep. 1987; 102: 361-368.

[90] Gittelsohn J, Rowan M. Preventing diabetes and obesity in American Indian communities: the potential of environmental interventions. American Journal of Clinical Nutrition. 2011; 93: 1179S-83S.

[91] Kuhnlein HV, Calloway DH. Minerals in human teeth: differences between preindustrial and contemporary Hopi Indians. American Journal of Clinical Nutrition. 1977; 30: 883886.

[92] Lindberg SM, Adams AK, Prince RJ. Early predictors of obesity and cardiovascular risk among American Indian children. Maternal Child Health Journal. 2010; 16: 1879-1886.

[93] Hodge FS, Maliski S, Cadogan M, Itty TL, Cardoza B. Learning How to Ask: Reflections on Engaging American Indian Research Participants. Am Indian Cult Res J. 2010; 34: 77-90.

[94] Fialkowski MK, Okoror TA, Boushey CJ. The relevancy of community-based methods: using diet within Native American and Alaska Native adult populations as an example. ClinTransl Sci. 2012; 5: 295-300.

[95] LaNoue M, Graeber DA, Helitzer DL, Fawcett J. Negative affect predicts adults' ratings of the current, but not childhood, impact of adverse childhood events. Community Mental Health Journal 49: 560-566.

[96] Fuemmeler BF, Dedert E, McClernon FJ, Beckham JC. Adverse childhood events are associated with obesity and disordered eating: results from a U.S. population-based survey of young adults. J Trauma Stress. 2009; 22: 329-333.

[97] Hodge F, Stemmler MS, Nandy K (2014). Association between Obesity and History of Abuse among American Indians in Rural California. Journal of Obesity Weight Loss Therapy 4: 208. doi: 10.4172/2165-7904.1000208.

[98] National Indian Child Welfare Association. https://www. nicwa.org/about-icwa/.

[99] National Indian Child Welfare Association. https://www. nicwa.org/

[100] Bureau of Indian Affairs. Indian Child Welfare Act. https:// www.bia.gov/bia/ois/dhs/icwa.

[101] Droske Timothy. Correcting Native American Sentencing Disparity Post-Booker. 91 MARQ LAW. REV. 723, 811 (2008).

[102] Droske Timothy. Correcting Native American Sentencing Disparity Post-Booker. 91 MARQ LAW. REV. 724, 811 (2008).

[103] The Constitution of the United States. Amendment V. 1789. 
[104] Flanagin J. Native Americans are the unseen victims of a broken US justice system. Quartz Media Inc. April 27, 2015 Retrieved June 15, 2018 from https://qz.com/392432/nativeamericans-are-the-unseen-victims-of-a-broken-us-justicesystem/.

[105] Prison Policy Initiative, United States incarceration rates by race/ethnicity, 2010, available at https:/www.prisonpolicy. org/graphs/2010rates/UShtml citing US census, Summary file 1.

[106] Leonardson Gary R. Native American Crime in the northwest: 2004-2005 - BIA information from Alaska, Montana, Wyoming, Idaho, Oregon, and Washington. Montana Board of Crime Control 5 (2006)

[107] Minton TD. Jails in Indian Country, 2013. http://tioa.ncai. org/files/jic13_emb.pdf (page 5).

[108] Henry M, Wyatt R, Rosenthal L et al. U.S. Department of Housing and Urban Development. The 2016 annual homeless assessment report to Congress. Washington, DC. November 2016
[109] Tasker John P. Confusion reigns over number of missing, murdered Indigenous women. Canadian Broadcast news. February 16, 2016. Retrieved at https://www.cbc.ca/ news/politics/mmiw-4000-hajdu-1.3450237.

[110] Lucchesse A. Murdered and Missing Indigenous Women (MMIW) database. Statistics. Retrieved at https://www. mmiwdatabase.com/about.

[111] Rosay A. Department of Justice. National Institute of Justice. Violence against American Indian and Alaska Native women and men. October 19, 2016. Retrieved at https:/ nij.gov/journals/277/Pages/violence-against-american-indi ans-alaska-natives.aspx.

[112] Bleir G, Zoledziowski. Hate in America. News 21. Cases of missing and murdered Native American women challenge police, courts. August 15, 2018. Retrieved at https://hateinamerica.news21.com/cases-of-missing-murd ered-native-american-women-challenge-police-courts/. 